\title{
KARAKTERISTIK PERILAKU BEKERJA DARI RUMAH SELAMA PANDEMI COVID-19 TERHADAP FREKUENSI PERJALANAN SEHARI-HARI
}

\author{
Rudy Suko Haryanto ${ }^{1}$ dan Leksmono Suryo Putranto ${ }^{2}$ \\ ${ }^{1}$ Program Studi Sarjana Teknik Sipil, Universitas Tarumanagara, Jl. Letjen S. Parman No.1 Jakarta \\ rudy.325150102@stu.untar.ac.id \\ ${ }^{2}$ Program Studi Sarjana Teknik Sipil, Universitas Tarumanagara, Jl. Letjen S. Parman No.1 Jakarta \\ leksmonop@ft.untar.ac.id
}

Masuk: 11-01-2021, revisi: 23-02-2021, diterima untuk diterbitkan: 23-02-2021

\begin{abstract}
During this pandemic, the government enforced PSBB so that the majority of office workers were required to do work from home (work from home). However, there are still many problems with people who can do their work from home and people who have to come to their place of work. Therefore this study aims to determine the frequency of trips of the Jabodetabek community based on the trips they took during PSBB period which was enforced by the government. This research was conducted online by distributing online questionnaires to people who live in Jabodetabek and who are already working. Processing data analysis using the help of the Statistical Package for the Social Sciences (SPSS) application. Based on the processed data, the results are, there is no significant difference between respondents who do work from home and not. Based on the characteristics table during PSBB, respondents who work from home tend to meet clients via video call compared to respondents who do not work from. home. Based on the characteristics table before PSBB, respondents who work from home tend to be stuck in traffic when leaving or coming home from work compared to respondents who do not work from home.
\end{abstract}

Keywords: PSBB; Work from home; questionnaire; Statistical package for the social sciences (SPSS); Trip frequency

\begin{abstract}
ABSTRAK
Dimasa pandemi ini, pemerintah memberlakukan PSBB sehingga mayoritas pekerja kantoran diwajibkan untuk melakukan pekerjaan dari rumah (work from home). Akan tetapi masih terdapat banyak masalah pada orang-orang yang bisa melakukan pekerjaannya dari rumah dan orang yang harus datang ke tempat mereka bekerja. Oleh sebab itu penelitian ini bertujuan untuk mengetahui frekuensi perjalanan masyarak jabodetabek berdasarkan perjalanan yang mereka lakukan saat masa PSBB yang diberlakukan oleh Pemerintah. Penelitian ini dilakukan secara online dengan menyebarkan kuesioner online kepada orang-orang yang berdomisili di jabodetabek dan yang sudah bekerja. Pengolahan analisis data menggunakan bantuan aplikasi Statistical Package for the Social Sciences (SPSS). Berdasarkan data yang sudah diolah didapatkan hasil yaitu, Berdasarkan tabel karakteristik saat PSBB,responden yang melakukan work from home cenderung bertemu client via video call di banding responden yang tidak melakukan work from home. Berdasarkan tabel karakteristik sebelum PSBB responden yang melakukan work from home cenderung terjebak kemacetan saat berangkat atau pulang kerja di bandingkan responden yang tidak melakukan work from home.
\end{abstract}

Kata kunci: PSBB; Bekerja dari rumah; Kuesioner; Statistical package for the social sciences (SPSS); Frekuensi perjalanan

\section{PENDAHULUAN}

Sudah hampir enam bulan kebijakan bekerja dari rumah (work from home) diberlakukan sejak 16 Maret 2020. Work from home (WFH) identik dengan melakukan pekerjaan kantor, rapat, diskusi, dan koordinasi dengan rekan dan atau mitra kerja dari rumah pegawai masing-masing secara online. Adapun pilihan media yang digunakan bisa berupa voice call, chat/text messenger, dan confrence call audio/video. Beberapa pilihan aplikasi video conference pun saat ini beragam seperti Google meet, microsoft team, zoom, skype dan lain sebagainya. Data survei online tentang dampak darurat virus corona terhadap buruh/karyawan menunjukkan bahwa sebanyak 51 persen karyawan tetap bekerja namun hanya dari rumah/tidak ke kantor/tempat kerja (P2 Kependudukan dan LD-UI,2020). Bekerja dari rumah atau work from home yang dilaksanakan saat ini merupakan tindak lanjut atas imbauan Presiden Joko Widodo pada konferensi pers di Istana Bogor Jawa Barat (15 Maret 2020). Presiden mengimbau agar dapat meminimalisasi 
penyebaran virus corona tipe baru (SARS-CoV-2) penyebab Covid-19, masyarakat diminta untuk bekerja, belajar, dan beribadah dari rumah, salah satunya menciptakan sistem bekerja dari rumah. Imbauan ini, khususnya untuk aparatur sipil negara, telah ditindaklanjuti oleh menteri pendayagunaan aparatur negara dan reformasi birokrasi melalui surat edaran nomor 19 tahun 2020 tentang penyesuaian sistem kerja aparatur Sipil negara dalam upaya pencegahan Covid-19 di lingkungan instansi pemerintah. Isinya, ASN dapat bekerja di rumah/tempat tinggal, tetapi dipastikan ada dua level pejabat struktural tertinggi yang bekerja di kantor. Selain itu, ada larangan kegiatan tatap muka yang menghadirkan banyak peserta untuk ditunda atau dibatalkan. Sebelumnya, sejumlah perusahaan swasta di Jakarta juga telah mengeluarkan kebijakan bekerja dari rumah (work from home). Perusahaan tersebut misalnya unilever, nestle, prudential, Coca Cola, HSBC, indofood, dan Frissian flag. Setiap perusahaan mempunyai kebijakan sendiri, seperti membagi dua tim yang secara bergantian bekerja di rumah dan di kantor serta bekerja dari rumah hanya diperuntukkan bagi mereka yang sakit dan baru dari perjalanan ke luar negeri. Ataupun hanya menerapkan bekerja di rumah selama beberapa hari karena untuk keperluan penyemprotan disinfektan. Terlepas dari pandemi COVID-19 yang menghantui setiap manusia di muka bumi ini, skema WFH patut dijadikan alternatif cara kerja baru, khususnya bagi jenis-jenis pekerjaan yang bukan bersifat pelayanan publik. Bahkan beberapa perusahaan swasta asing sudah menerapkan skema ini jauh lebih dulu tanpa embel-embel pandemi. Koordinasi pegawai secara tatap muka di kantor hanya dilakukan berkala dan terjadwal, selebihnya pegawai bekerja secara online di rumah masing-masing. Jika setengah saja dari perusahaan/lembaga menerapkan skema ini di kota jakarta, maka selain produktifitas kerja yang diharapkan akan lebih tinggi, permasalahan kemacetan dan polusi udara praktis diharapkan juga bisa teratasi.

\section{Work from home}

Menurut Crosbie \& Moore (2004), bekerja dari rumah berarti pekerjaan berbayar yang dilakukan terutama dari rumah (minimal 20 jam per minggu). Bekerja dari rumah akan memberikan waktu yang fleksibel bagi pekerja untuk memberikan keseimbangan hidup bagi karyawan. Disisi lain juga memberikan keuntungan bagi perusahaan.

Menurut Muslimah (2020) Work from home adalah suatu istilah bekerja dari jarak jauh, lebih tepatnya bekerja dari rumah. Jadi pekerja tidak perlu datang ke kantor tatap muka dengan para pekerja lainnya. Secara umum biasanya work from home diartikan dengan cara kerja karyawan yang berada di luar kantor. Entah dari rumah, dari cafe atau restoran sesuai dengan keinginan karyawan. Sistem kerja WFH memang memiliki fleksibilitas yang tinggi. Hal ini guna mendukung keseimbangan karyawan antara pekerjaan dan kehidupan.

\section{Pembatasan Sosial Berskala Besar (PSBB)}

PSBB adalah istilah kekarantinaan kesehatan di Indonesia yang didefinisikan sebagai "Pembatasan kegiatan tertentu penduduk dalam suatu wilayah yang diduga terinfeksi penyakit dan/atau terkontaminasi sedemikian rupa untuk mencegah kemungkinan penyebaran penyakit atau kontaminasi." PSBB merupakan salah satu jenis penyelenggaraan kekarantinaan kesehatan di wilayah, selain karantina rumah, karantina rumah sakit, dan karantina wilayah. Tujuan PSBB yaitu mencegah meluasnya penyebaran penyakit kedaruratan kesehatan masyarakat (KKM) yang sedang terjadi antarorang di suatu wilayah tertentu. Pembatasan kegiatan yang dilakukan paling sedikit meliputi peliburan sekolah dan tempat kerja, pembatasan kegiatan keagamaan, dan/atau pembatasan kegiatan di tempat atau fasilitas umum. PSBB dilakukan oleh pemerintah daerah tingkat provinsi maupun kabupaten/kota setelah mendapatkan persetujuan menteri kesehatan melalui keputusan menteri. (KemenkesRI, 2020).

\section{Pembatasan moda transportasi}

Transportasi adalah alat yang digunakan untuk mengangkut manusia, hewan dan barang ketempat tujuan. Menurut Nasution (1996) transportasi diartikan sebagai pemindahan barang dan manusia dari tempat asal ke tempat tujuan. PSBB yang dijalani oleh Gubernur DKI jakarta bapak Anies Baswedan sejak 16 maret 2020 menghasilkan 4 kebijakan dalam transportasi untuk mencegah penularan Covid-19 di Jakarta yaitu, membatasi operasional MRT,pembatasan oprasional LRT,transjakarta hanya melayani 13 koridor,menangguhkan ganjil genap.

\section{Meliburkan tempat kerja}

Menurut permenkes 9 tahun 2020 tentang pedoman PSBB dalam rangka percepatan penanganan COVID-19 yang dimaksud dengan peliburan tempat kerja adalah pembatasan proses bekerja di tempat kerja dan menggantinya dengan proses bekerja di rumah/ Work From Home, untuk menjaga produktivitas dan kinerja pekerja.

\section{Job Engagement Scale (JES)}

Skala keterlibatan kerja dikembangkan oleh (Rich, 2010) berdasarkan Kahn (1990) definisi keterlibatan karyawan dan tiga dimensinya: fisik, kognitif, dan emosional keterikatan. Setiap dimensi diwakili oleh enam pertanyaan. Peserta menilai level mereka keterlibatan karyawan pada skala Likert 4 poin $(1=$ Sangat Tidak Setuju hingga $4=$ 
Sangat Setuju). Item contoh termasuk: "Saya bekerja dengan intensitas pada pekerjaan saya" (fisik), "Saya sangat antusias pekerjaan saya "(emosional), dan“" Di tempat kerja, pikiran saya berfokus pada pekerjaan saya "(kognitif).

\section{Telecommuting}

Telecommuting pertama kali dicetuskan oleh Jack Niles pada tahun 1973, yaitu jenis pekerjaan yang dapat dilakukan di lokasi yang tidak membutuhkan banyak waktu untuk pergi dan pulang ke tempat kerja, pekerjaan yang dapat dilakukan di dalam rumah atau di lokasi kerja yang lain, dan difasilitasi oleh jaringan internet/ komputer/ telepon, termasuk peralatan kerja lain seperti alat tulis kantor (ATK). Pemerintah amerika serikat mendefinisikan telecommuting sebagai kemampuan untuk melakukan pekerjaan di lokasi selain dari kantor resmi, yang dilakukan secara rutin, teratur, dan dilakukan lebih dari satu hari dalam sepekan (Woog dalam Olorunfemi , 2013).

\section{METODE PENELITIAN}

Metode pengumpulan data yang digunakan dalam penelitian ini adalah dengan melakukan penyebaran kuesioner secara online. Penelitian ini diawali dengan studi pedahuluan, tinjauan pustaka, penentuan target responden, kemudian melakukan penyebaran kuesioner secara online dengan target individu yang sudah bekerja khususnya yang masih bekerja di masa pandemi Covid-19. Setelah pengumpulan data selesai maka akan dilakukan analisis untuk mengetahui tingkat keefektifan work from home yang saat ini sedang di terapkan oleh pemerintah dalam program PSBB. Penelitian ini menggunakan skala likert. skala likert terdiri dari empat pernyataan yaitu Sangat Tidak Setuju, Tidak Setuju, Setuju, Sangat Setuju. Setelah data diolah akan di lakukan uji validitas dan reabilitas, lalu akan mendapatkan data-data yang valid dan reabel seusai yang di inginkan. Setelah itu di lakukan uji coba menggunakan independent sample t-test yang di gunakan untuk membandingkan apakah ada perbedaan yang signifikan atau berarti pada nilai rataan suatu variable antara responden yang melakukan work from home dan responden yang tidak melakukan work from home. Pengujian dilakukan dengan program IBM SPSS versi 22. Dari hasil analisis ini kemudian akan disusun kesimpulan dan saran.

Perancangan sistem dapat di rancang dalam bentuk diagram alir, yang merupakan alat yang dapat digunakan untuk menujukan urutan dari proses pembuatan sistem dapat dilihat dari diagram alir pada gambar 1 di bawah ini.

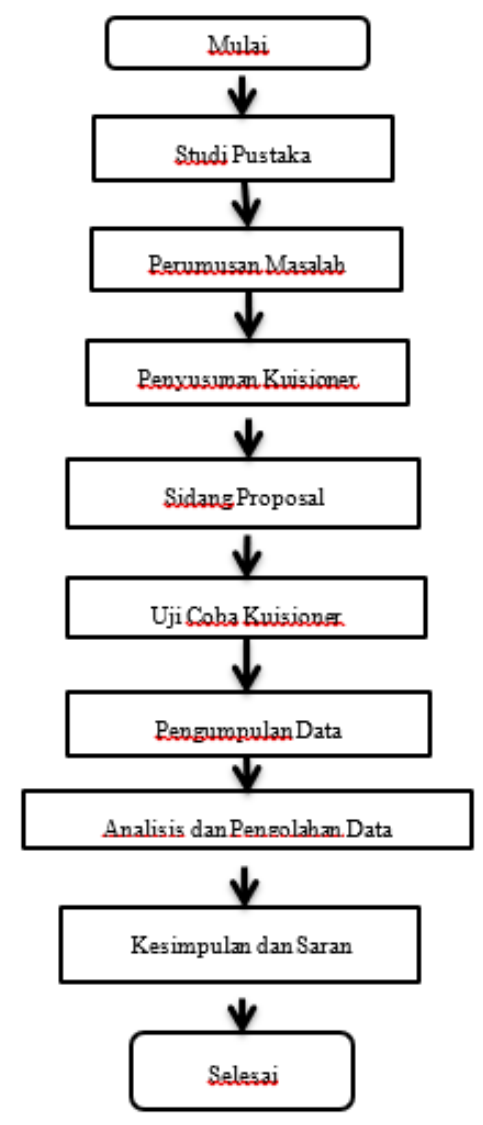

Gambar 1. Diagram alir 


\section{HASIL DAN PEMBAHASAN}

Pada awal perencanaan penyebaran kuesioner ini. ditargetkan sebanyak 150 responden yang berdomisili di Jabodetabek. Akan tetapi pada realisasinya jumlah responden yang didapatkan adalah sebanyak 180 responden. Data yang dipakai adalah 159 data responden yang berdomisili di Jabodetabek. Dikarenakan sudah memenuhi kuota yang ditargetkan. Berikut adalah kumpulan daftar pertanyaan yang digunakan untuk kuesioner, dapat dilihat pada tabel 1 .

Tabel 1. Daftar pertanyaan kuesioner

\begin{tabular}{|c|c|}
\hline No & Pertanyaan karakteristik jenis pekerjaan \\
\hline 1 & Saya menggunakan email kurang dari sekali dalam sebulan \\
\hline 2 & Saya berurusan dengan orang yang melakukan kekerasan setidaknya sekali seminggu \\
\hline 3 & Saya bekerja di luar ruangan setiap hari \\
\hline 4 & Saya terkena penyakit atau infeksi disetidaknya sekali seminggu \\
\hline 5 & Saya mengalami kecelakaan kerja setidaknya sekali seminggu \\
\hline 6 & Saya menghabiskan sebagian besar waktu berjalan atau berlari \\
\hline 7 & $\begin{array}{c}\text { Saya menghabiskan sebagian besar waktu dengan mengenakan atau peralatan pelindung atau } \\
\text { keamanan khusus }\end{array}$ \\
\hline 8 & Melakukan aktivitas fisik umum sangat penting untuk saya \\
\hline 9 & Menangani dan memindahkan objek sangat penting untuk saya \\
\hline 10 & Mesin dan proses pengendali [bukan komputer atau kendaraan] sangat penting untuk saya \\
\hline 11 & Mengoperasikan kendaraan, perangkat mekanis, atau peralatan sangat penting untuk saya \\
\hline 12 & Tampil untuk atau bekerja secara langsung dengan publik sangatlah penting unutk saya \\
\hline 13 & Memperbaiki dan merawat peralatan mekanik sangatlah penting untuk saya \\
\hline 14 & Memperbaiki dan merawat peralatan elektronik sangatlah penting untuk saya \\
\hline 15 & Memeriksa peralatan, struktur, atau bahan sangat penting untuk saya \\
\hline No & Pertanyaan karakteristik keterikatan kerja \\
\hline 1 & Saya bekerja dengan intens dalam pekerjaan saya \\
\hline 2 & Saya berusaha maksimal untuk pekerjaan saya \\
\hline 3 & Saya menyediakan banyak energi untuk pekerjaan saya \\
\hline 4 & Saya berusaha sekuat tenaga untuk melakukan pekerjaan saya dengan baik \\
\hline 5 & Saya berusaha sekuat tenaga untuk menyelesaikan pekerjaan saya \\
\hline 6 & Saya menggunakan banyak energi untuk pekerjaan saya \\
\hline 7 & Saya antusias dengan pekerjaan saya \\
\hline 8 & Saya merasa energik dengan pekerjaan saya \\
\hline 9 & Saya tertarik dengan pekerjaan saya \\
\hline 10 & Saya bangga dengan pekerjaan saya \\
\hline 11 & Saya merasa pekerjaan saya lakukan adalah positif \\
\hline 12 & Saya senang dengan pekerjaan saya \\
\hline 13 & Di tempat kerja, pikiran saya terfokus pada pekerjaan saya \\
\hline 14 & Di tempat kerja, saya menaruh banyak perhatian pada pekerjaan saya \\
\hline
\end{tabular}


Tabel 2. Daftar pertanyaan kuesioner (lanjutan)

\begin{tabular}{cr}
\hline No & Pertanyaan karakteristik jenis pekerjaan \\
\hline 15 & Di tempat kerja, saya berkonsentrasi pada pekerjaan saya \\
16 & Di tempat kerja, saya memusatkan banyak perhatian pada pekerjaan saya \\
17 & Di tempat kerja, saya asik dengan pekerjaan saya \\
18 & Di tempat kerja, saya menyediakan banyak perhatian pada pekerjaan saya \\
\hline No & Pertanyaan frekuensi perjalanan sebelum dan sesudah PSBB \\
1 & Saya pergi ke tempat kerja menggunakan kendaraan pribadi \\
3 & Saya terjebak kemacetan saat berangkat/pulang kerja \\
4 & Saya makan bersama keluarga di rumah \\
5 & Saya pergi ke tempat ibadah menggunakan kendaraan pribadi \\
6 & Saya bertemu dengan client di café/restoran \\
7 & Saya bertemu dengan client via video call / aplikasi sejenis \\
8 & Saya berbelanja ditoko online \\
9 & Saya pergi berkumpul Bersama rekan-rekan secara langsung setelah jam kerja \\
10 & Sayal menaliskan akhir pekan saya Bersama rekan kerja saya \\
\hline
\end{tabular}

Dapat dilihat dari tabel 2 sampai tabel 5 tentang jenis pekerjaan dapat dilihat bahwa terdapat empat indikator pertanyaan kuesioner yang memiliki perbedaan nilai rataan yang signifikan antara responden yang melakukan work from home dan yang tidak melakukan work from home.

Tabel 3. Skor selisih rataan dari kesesuaian jenis pekerjaan

\begin{tabular}{cccccc}
\hline Keterangan & $\mathrm{N}$ & \multicolumn{4}{c}{ Skor Selisih Rataan } \\
\cline { 2 - 5 } & & $\begin{array}{c}\text { Penggunaan } \\
\text { email kurang } \\
\text { dari sekali } \\
\text { sebulan }\end{array}$ & $\begin{array}{c}\text { Berurusan dengan } \\
\text { pekerja kasar } \\
\text { seminggu sekali }\end{array}$ & $\begin{array}{c}\text { Bekerja di } \\
\text { luar } \\
\text { ruangan } \\
\text { setiap hari }\end{array}$ & $\begin{array}{c}\text { Terkena } \\
\text { penyakit } \\
\text { seminggu } \\
\text { sekali }\end{array}$ \\
\hline WFH & 1,31 & 1,36 & 1,91 & 1,2 \\
\hline Tidak WFH & 69 & 2,18 & 2,00 & 2,67 & 1,12 \\
Selisih Rataan & $-0,87$ & $-0,636$ & $-0,758$ & 0,085 \\
Tingkat Signifikan & 0,001 & 0,001 & 0,001 & 0,168 \\
Signifikan? (Ya/Tidak) & Ya & Ya & Ya & Tidak \\
\hline
\end{tabular}

Tabel 4. Skor selisih rataan dari kesesuaian jenis pekerjaan

\begin{tabular}{cccccc}
\hline Keterangan & $\mathrm{N}$ & \multicolumn{4}{c}{ Skor Selisih Rataan } \\
\cline { 2 - 5 } & & $\begin{array}{c}\text { Mengalami } \\
\text { kecelakaan } \\
\text { kerja } \\
\text { seminggu } \\
\text { sekali }\end{array}$ & $\begin{array}{c}\text { Menghabiskan } \\
\text { sebagian besar } \\
\text { waktu untuk } \\
\text { berjalan/berlari }\end{array}$ & $\begin{array}{c}\text { Mengguna } \\
\text { kan } \\
\text { peralatan } \\
\text { pelindung } \\
\text { khusus }\end{array}$ & $\begin{array}{c}\text { Melakukan } \\
\text { aktivitas fisik } \\
\text { umum sangat } \\
\text { penting }\end{array}$ \\
\hline $\begin{array}{c}\text { WFH } \\
\text { Tidak WFH }\end{array}$ & 1,16 & 1,93 & 1,99 & 2,87 \\
\cline { 2 - 5 } Selisih Rataan & 69 & 1,38 & 2,57 & 2,12 & 3,18 \\
Tingkat Signifikan & & $-0,222$ & $-0,637$ & $-0,127$ & $-0,315$ \\
Signifikan? (Ya/Tidak) & & 0,073 & 0,001 & 0,477 & 0,32 \\
Tidak & Ya & Tidak & Tidak \\
\hline
\end{tabular}


Tabel 5. Skor selisih rataan dari kesesuaian jenis pekerjaan

\begin{tabular}{cccccc}
\hline Keterangan & $\mathrm{N}$ & \multicolumn{4}{c}{ Skor Selisih Rataan } \\
\cline { 2 - 5 } & & $\begin{array}{c}\text { Melakukan } \\
\text { kegiatan } \\
\text { pemindahan } \\
\text { objek }\end{array}$ & $\begin{array}{c}\text { Mesin dan proses } \\
\text { pengendali sangat } \\
\text { penting }\end{array}$ & $\begin{array}{c}\text { Perangkat } \\
\text { mekanis } \\
\text { sangat } \\
\text { penting }\end{array}$ & $\begin{array}{c}\text { Melayani } \\
\text { publik secara } \\
\text { langsung } \\
\text { sangat penting }\end{array}$ \\
\hline WFH & 99 & 2,87 & 2,49 & 2,36 & 2,61 \\
\hline Tidak WFH & 60 & 3,18 & 2,63 & 1,88 & 2,38 \\
Selisih Rataan & & $-0,318$ & 0,480 & 0,223 & $-0,125$ \\
Tingkat Signifikan & & 0,398 & 0,066 & 0,203 & 0,443 \\
Signifikan? (Ya/Tidak) & Tidak & Tidak & Tidak & Tidak \\
\hline
\end{tabular}

Tabel 6. Skor selisih rataan dari kesesuaian jenis pekerjaan

\begin{tabular}{ccccc}
\hline Keterangan & $\mathrm{N}$ & \multicolumn{3}{c}{ Skor Selisih Rataan } \\
\cline { 2 - 4 } & & $\begin{array}{c}\text { Memperbaiki } \\
\text { peralatan mekanik } \\
\text { sangat penting }\end{array}$ & $\begin{array}{c}\text { Memperbaiki } \\
\text { peralatan } \\
\text { elektronik sangat } \\
\text { penting }\end{array}$ & $\begin{array}{c}\text { Memeriksa } \\
\text { peralatan struktur } \\
\text { sangat penting }\end{array}$ \\
\hline WFH & 99 & 2,51 & 2,92 & 2,64 \\
Tidak WFH & 60 & 2,30 & 2,65 & 2,57 \\
\cline { 2 - 5 } Selisih Rataan & & 0,205 & 0,269 & 0,070 \\
Tingkat Signifikan & & 0,250 & 0,131 & 0,679 \\
Signifikan? (Ya/Tidak) & Tidak & Tidak & Tidak \\
\hline
\end{tabular}

Dapat dilihat dari tabel 6 sampai tabel 10 bisa dilihat semua indicator pertanyaan TIDAK memiliki perbedaan yang signifikan antara responden yang melakukan work from Home dan yang tidak melakukan work from gome.

Tabel 7. Skor selisih rataan dari kesesuaian keterikatan kerja

\begin{tabular}{cccccc}
\hline Keterangan & $\mathrm{N}$ & \multicolumn{4}{c}{ Skor Selisih Rataan } \\
\cline { 2 - 6 } & & $\begin{array}{c}\text { Bekerja intens } \\
\text { dalam } \\
\text { pekerjaan }\end{array}$ & $\begin{array}{c}\text { Berusaha } \\
\text { maksimal dalam } \\
\text { pekerjaan }\end{array}$ & $\begin{array}{c}\text { Menyediakan } \\
\text { banyak energi } \\
\text { untuk pekerjaan }\end{array}$ & $\begin{array}{c}\text { Berusaha sekuat } \\
\text { tenaga untuk } \\
\text { melakukan } \\
\text { pekerjaan }\end{array}$ \\
\hline $\begin{array}{c}\text { WFH } \\
\text { Tidak WFH }\end{array}$ & 99 & 3,33 & 3,63 & 3,34 & 3,58 \\
\cline { 2 - 6 } Selisih Rataan & 60 & 3,30 & 3,55 & 3,45 & 3,52 \\
Tingkat Signifikan & & 0,033 & 0,076 & $-0,107$ & 0,059 \\
Signifikan? (Ya/Tidak) & & 0,735 & 0,409 & 0,342 & 0,543 \\
\hline
\end{tabular}

Tabel 8. Skor selisih rataan dari kesesuaian keterikatan kerja

\begin{tabular}{cccccc}
\hline Keterangan & $\mathrm{N}$ & \multicolumn{4}{c}{ Skor Selisih Rataan } \\
\cline { 2 - 5 } & & $\begin{array}{c}\text { Berusaha } \\
\text { sekuat tenaga } \\
\text { untuk } \\
\text { menyelesaikan } \\
\text { pekerjaan }\end{array}$ & $\begin{array}{c}\text { Menggunakan } \\
\text { banyak energi } \\
\text { untuk pekerjaan }\end{array}$ & $\begin{array}{c}\text { Antusias } \\
\text { terhadap } \\
\text { pekerjaan saat } \\
\text { ini }\end{array}$ & $\begin{array}{c}\text { Merasa energik } \\
\text { dengan } \\
\text { pekerjaan }\end{array}$ \\
\hline $\begin{array}{c}\text { WFH } \\
\text { Tidak WFH }\end{array}$ & 99 & 3,63 & 3,19 & 3,34 & 3,22 \\
Selisih Rataan & 60 & 3,57 & 3,37 & 3,32 & 3,25 \\
Tingkat Signifikan & & 0,060 & $-0,175$ & 0,027 & $-0,028$ \\
Signifikan? (Ya/Tidak) & & 0,502 & 0,154 & 0,806 & 0,808 \\
\hline
\end{tabular}


Tabel 9. Skor selisih rataan dari kesesuaian keterikatan kerja

\begin{tabular}{cccccc}
\hline Keterangan & $\mathrm{N}$ & \multicolumn{4}{c}{ Skor Selisih Rataan } \\
\cline { 2 - 6 } & & $\begin{array}{c}\text { Bangga } \\
\text { dengan } \\
\text { pekerjaan saat } \\
\text { ini }\end{array}$ & $\begin{array}{c}\text { Merasa pekerjaan } \\
\text { saat ini bersifat } \\
\text { positif }\end{array}$ & $\begin{array}{c}\text { Senang dengan } \\
\text { pekerjaan saat } \\
\text { ini }\end{array}$ & $\begin{array}{c}\text { Di tempat kerja } \\
\text { pikiran saya } \\
\text { terfokus pada } \\
\text { pekerjaan }\end{array}$ \\
\hline WFH & 99 & 3,43 & 3,55 & 3,41 & 3,20 \\
\hline Tidak WFH & 60 & 3,38 & 3,65 & 3,43 & 3,15 \\
\cline { 2 - 6 } Selisih Rataan & 0,051 & $-0,105$ & $-0,019$ & 0,052 \\
Tingkat Signifikan & & 0,616 & 0,220 & 0,851 & 0,624 \\
Signifikan? (Ya/Tidak) & Tidak & Tidak & Tidak & Tidak \\
\hline
\end{tabular}

Tabel 10. Skor selisih rataan dari kesesuaian keterikatan kerja

\begin{tabular}{cccccc}
\hline Keterangan & $\mathrm{N}$ & \multicolumn{4}{c}{ Skor Selisih Rataan } \\
\cline { 2 - 6 } & & $\begin{array}{c}\text { Tertarik } \\
\text { dengan } \\
\text { pekerjaan saat } \\
\text { ini }\end{array}$ & $\begin{array}{c}\text { Menaruh banyak } \\
\text { perhatian pada } \\
\text { pekerjaan }\end{array}$ & $\begin{array}{c}\text { Berkonsentrasi } \\
\text { pada pekerjaan }\end{array}$ & $\begin{array}{c}\text { Memusatkan } \\
\text { banyak } \\
\text { perhatian pada } \\
\text { pekerjaan }\end{array}$ \\
\hline WFH & 99 & 3,36 & 3,33 & 3,26 & 3,22 \\
\hline Tidak WFH & 60 & 3,35 & 3,28 & 3,42 & 3,33 \\
Selisih Rataan & 0,014 & 0,050 & $-0,154$ & $-0,111$ \\
Tingkat Signifikan & & 0,893 & 0,604 & 0,110 & 0,275 \\
Signifikan? (Ya/Tidak) & Tidak & Tidak & Tidak & Tidak \\
\hline
\end{tabular}

Tabel 11. Skor selisih rataan dari kesesuaian keterikatan kerja

\begin{tabular}{cccc}
\hline Keterangan & $\mathrm{N}$ & \multicolumn{2}{c}{ Skor Selisih Rataan } \\
\cline { 2 - 4 } & & $\begin{array}{c}\text { Asik dengan } \\
\text { pekerjaan }\end{array}$ & $\begin{array}{c}\text { Menyediakan } \\
\text { banyak perhatian } \\
\text { pada pekerjaan }\end{array}$ \\
\hline WFH & 99 & 3,21 & 3,26 \\
\hline Tidak WFH & 60 & 3,37 & 3,37 \\
Selisih Rataan & & $-0,121$ & $-0,104$ \\
Tingkat Signifikan & & 0,216 & 0,276 \\
Signifikan? (Ya/Tidak) & & Tidak & Tidak \\
\hline
\end{tabular}

Dapat dilihat dari tabel 11 sampai tabel 13 tentang frekuensi perjalanan saat PSBB dapat dilihat ada 6 indikator yang memiliki perbedaan yang signifikan antara responden yang melakukan work from home dan tidak melakukan work from home.

Tabel 12. Skor selisih rataan dari frekuensi perjalanan saat PSBB

\begin{tabular}{cccccc}
\hline Keterangan & $\mathrm{N}$ & \multicolumn{4}{c}{ Skor Selisih Rataan } \\
\cline { 2 - 6 } & $\begin{array}{c}\text { Pergi bekerja } \\
\text { menggunakan } \\
\text { kendaraan } \\
\text { pribadi }\end{array}$ & $\begin{array}{c}\text { Terjebak } \\
\text { kemacetan saat } \\
\text { berangkat/pulang } \\
\text { kerja }\end{array}$ & $\begin{array}{c}\text { Makan Bersama } \\
\text { keluarga di } \\
\text { rumah }\end{array}$ & $\begin{array}{c}\text { pergi ibadah } \\
\text { menggunakan } \\
\text { kendaraan } \\
\text { pribadi }\end{array}$ \\
\hline WFH & 99 & 3,08 & 2,86 & 3,15 & 2,86 \\
\hline Tidak WFH & 60 & 3,10 & 2,15 & 3,00 & 2,42 \\
Selisih Rataan & $-0,19$ & 0,709 & 0,152 & 0,442 \\
Tingkat Signifikan & 0,918 & 0,001 & 0,308 & 0,027 \\
Signifikan? (Ya/Tidak) & Tidak & Ya & Tidak & Ya \\
\hline
\end{tabular}


Tabel 13. Skor Selisih rataan dari frekuensi perjalanan saat PSBB

\begin{tabular}{cccccc}
\hline Keterangan & $\mathrm{N}$ & \multicolumn{4}{c}{ Skor Selisih Rataan } \\
\cline { 2 - 5 } & & $\begin{array}{c}\text { Bertemu client } \\
\text { di } \\
\text { café/restoran }\end{array}$ & $\begin{array}{c}\text { Bertemu client via } \\
\text { video call }\end{array}$ & $\begin{array}{c}\text { Berbelanja di } \\
\text { toko online }\end{array}$ & $\begin{array}{c}\text { Pergi ke mall } \\
\text { bersama } \\
\text { keluarga }\end{array}$ \\
\hline WFH & 99 & 2,31 & 3,03 & 3,42 & 2,58 \\
Tidak WFH & 60 & 1,83 & 1,83 & 3,37 & 2,08 \\
Selisih Rataan & & 0,480 & 1,197 & 0,058 & 0,492 \\
Tingkat Signifikan & & 0,004 & 0,001 & 0,639 & 0,003 \\
Signifikan? (Ya/Tidak) & & Ya & Ya & Tidak & Tidak \\
\hline
\end{tabular}

Tabel 14. Skor Selisih rataan dari frekuensi perjalanan saat PSBB

\begin{tabular}{cccc}
\hline Keterangan & $\mathrm{N}$ & \multicolumn{2}{c}{ Skor Selisih Rataan } \\
\cline { 2 - 4 } & & $\begin{array}{c}\text { Berkumpul } \\
\text { bersama rekan } \\
\text { kerja } \\
\text { jam kerja }\end{array}$ & $\begin{array}{c}\text { Menghabiskan } \\
\text { akhir pekan } \\
\text { bersama rekan } \\
\text { kerja }\end{array}$ \\
\hline WFH & 99 & 2,36 & 2,17 \\
Tidak WFH & 60 & 1,85 & 1,53 \\
\cline { 2 - 4 } Selisih Rataan & & 0,514 & 0,638 \\
Tingkat Signifikan & & 0,001 & 0,001 \\
Signifikan? (Ya/Tidak) & & Ya & Ya \\
\hline
\end{tabular}

Dapat dilihat dari tabel 14 sampai tabel 16 tentang frekuensi perjalanan sebelum PSBB dapat dilihat ada 6 indikator yang memiliki perbedaan yang signifikan antara responden yang melakukan work from home dan tidak melakukan work from home.

Tabel 15. Skor selisih rataan dari frekuensi perjalanan sebelum PSBB

\begin{tabular}{cccccc}
\hline Keterangan & $\mathrm{N}$ & \multicolumn{4}{c|}{ Skor Selisih Rataan } \\
\cline { 2 - 5 } & & $\begin{array}{c}\text { Pergi bekerja } \\
\text { menggunakan } \\
\text { kendaraan } \\
\text { pribadi }\end{array}$ & $\begin{array}{c}\text { Terjebak } \\
\text { kemacetan saat } \\
\text { berangkat/pulang } \\
\text { kerja }\end{array}$ & $\begin{array}{c}\text { Makan bersama } \\
\text { keluarga di } \\
\text { rumah }\end{array}$ & $\begin{array}{c}\text { pergi ibadah } \\
\text { menggunakan } \\
\text { kendaraan } \\
\text { pribadi }\end{array}$ \\
\hline WFH & 99 & 3,15 & 3,17 & 3,00 & 3,07 \\
\hline Tidak WFH & 60 & 3,15 & 2,30 & 2,95 & 2,98 \\
Selisih Rataan & & 0,002 & 0,872 & 0,050 & 0,087 \\
Tingkat Signifikan & 0,993 & 0,001 & 0,751 & 0,618 \\
Signifikan? (Ya/Tidak) & Tidak & Ya & Tidak & Tidak \\
\hline
\end{tabular}

Tabel 16. Skor selisih rataan dari frekuensi perjalanan sebelum PSBB

\begin{tabular}{cccccc}
\hline Keterangan & $\mathrm{N}$ & \multicolumn{4}{c}{ Skor Selisih Rataan } \\
\cline { 2 - 5 } & & $\begin{array}{c}\text { Bertemu client } \\
\text { di } \\
\text { café/restoran }\end{array}$ & $\begin{array}{c}\text { Bertemu client via } \\
\text { video call }\end{array}$ & $\begin{array}{c}\text { Berbelanja di } \\
\text { toko online }\end{array}$ & $\begin{array}{c}\text { Pergi ke mall } \\
\text { Bersama } \\
\text { keluarga }\end{array}$ \\
\hline WFH & 99 & 2,42 & 2,78 & 3,40 & 2,84 \\
Tidak WFH & 60 & 1,98 & 1,80 & 3,30 & 2,38 \\
Selisih Rataan & & 0,441 & 0,978 & 0,104 & 0,455 \\
Tingkat Signifikan & & 0,006 & 0,001 & 0,398 & 0,003 \\
Signifikan? (Ya/Tidak) & & Ya & Ya & Tidak & Ya \\
\hline
\end{tabular}


Tabel 17. Skor selisih rataan dari frekuensi perjalanan sebelum PSBB

\begin{tabular}{cccc}
\hline Keterangan & $\mathrm{N}$ & \multicolumn{2}{c}{ Skor Selisih Rataan } \\
\cline { 2 - 4 } & & $\begin{array}{c}\text { Berkumpul } \\
\text { bersama rekan } \\
\text { kerja setelah } \\
\text { jam kerja }\end{array}$ & $\begin{array}{c}\text { Menghabiskan } \\
\text { akhir pekan } \\
\text { bersama rekan } \\
\text { kerja }\end{array}$ \\
\hline WFH & 99 & 2,67 & 2,32 \\
\cline { 2 - 4 } Tidak WFH & 60 & 2,32 & 1,92 \\
Selisih Rataan & & 0,350 & 0,407 \\
Tingkat Signifikan & & 0,031 & 0,015 \\
Signifikan? (Ya/Tidak) & & Ya & Ya \\
\hline
\end{tabular}

\section{KESIMPULAN DAN SARAN}

\section{Kesimpulan}

Berdasarkan penelitian yang dilakukan dengan cara menyebarkan kuesioner secara online melalui google form dapat diambil kesimpulan sebagai berikut :

1. Berdasarkan 159 responden yang telah mengisi kuesioner ini, 99 orang responden melakuakam work from home dan 60 responden tidak melakukan work from home.

2. Berdasarkan tabel 2 sampai 5 tentang jenis pekerjaan dapat disimpulkan bahwa 4 indikator yang memiliki perbedaan yang signifikan antara responden yang melakukan work from home dan tidak antara lain:

1. Penggunaan email kurang dari sekali sebulan

2. Berurusan dengan pekerja kasar sekali dalam seminggu

3. Bekerja di luar ruangan setiap hari

4. Menghabiskan Sebagian besar waktu untuk berjalan/berlari

3. Berdasarkan tabel 6 sampai 10 tentang keterikatan kerja dapat disimpulkan bahwa semua indikator TIDAK memiliki perbedaan yang signifikan antara responden yang melakukan work from home dan tidak.

4. Berdasarkan tabel 11 sampai 13 tentang frekuensi perjalanan saat PSBB dapat disimpulkan bahwa 6 indikator yang memiliki perbedaan signifikan antara responden yang melakukan work from home dan tidak antara lain:

1. Terjebak kemacetan saat berangkat/pulang kerja

2. Pergi ibadah menggunakan kendaraan pribadi

3. Bertem client di café/restoran

4. Bertemu client via video call

5. Berkumpul bersama rekan kerja setelah jam kerja

6. Menghabiskan akhir pekan bersama rekan kerja

5. Berdasarkan tabel 14 sampai 16 tentang frekuensi perjalanan sebelum PSBB dapat di simpulkan bahwa 6 indikator yang memiliki perbedaan yang signifikan antara responden yang melakukan work from home dan tidak antara lain:

1. Terjebak kemacetan saat berangkat/pulang kerja

2. Bertem client di café/restoran

3. Bertemu client via video call

4. Pergi ke mall bersama keluarga

5. Berkumpul bersama rekan kerja setelah jam kerja

6. Menghabiskan akhir pekan bersama rekan kerja

\section{Saran}

Berdasarkan kesimpulan yang telah dibuat dinilai masih terdapat kekurangan dan kelebihan, ada pula hal-hal yang dapat di kembangkan sebagai berikut :

1. Penelitian ini dapat dimanfaatkan sebagai pertimbangan dalam upaya mengurangi frekuensi perjalanan harian dengan memberlakukan sistem work from home bagi karyawan yang dapat mengerjakan pekerjaannya dari rumah.

2. Hasil penelitian ini dapat digunakan sebagai bahan referensi atau rujukan untuk penelitian selanjutnya yang mempunyai tema serupa dengan penelitian ini. 
3. Hasil penelitian ini bisa digunakan untuk pihak-pihak pemilik usaha/bisnis yang dapat memberlakukan sistem work from home, maupun pihak pemerintahan untuk upaya mengurangi kemacetan pada perjalanan seharihari.

4. Hasil penelitian ini bisa menjadi pertimbangan pemerintah untuk tetap menerapkan work from home, melihat work from home ini mendapatkan respon yang baik dari masyarakat dikarenakan memiliki kelebihan seperti, tidak terjebak kemacetan saat ingin bekerja, lebih banyak waktu bersama keluarga, penghematan uang untuk membeli bahan bakar kendaraan, menghemat pengeluaran untuk uang tol dan sebagainya.

5. Jika setelah pandemi masyarakat cocok dengan sistem work from home, maka kedepannya sistem work frome home ini dapat terus dilakukan.

\section{DAFTAR PUSTAKA}

Crosbie, T dan J Moore. work-life balance and working from home. Middlesbrough: Teesside University, 2004.

Muslimah, Septina. Pengertian Work From Home (WFH) dan Tipsnya. 26 Maret 2020.

Nasution. Manajemen Transportasi. Jakarta: Ghalia Indonesia, 1996.

Olorunfemi, A. O. "Telecommuting to Improve Quality of Worklife of Women Workers in Lagos State Tertiary Institutions." (2013).

Rich, B. L., E. R. Crawford dan J. A. Lepine. "Job Engagement : Antecedents and Effects on Job Performance." Academy of Management Journ (2010): 617-635. 